Tatjana Glušac*

Faculty of Law and Business Studies

Dr Lazar Vrkatić, Novi Sad

\title{
Mira Milić
}

Faculty of Sports and Physical Education,

Novi Sad

\section{HOW UNIVERSITY TEACHERS OF ENGLISH FOR SPECIFIC PURPOSES AND THEIR STUDENTS EMPLOY DICTIONARIES IN TEACHING AND LEARNING ${ }^{* *}$}

This paper explores how tertiary level teachers of English for Specific Purposes (ESP) and their students use dictionaries in ESP teaching and learning. The study included 21 ESP teachers and 705 students from the University of Novi Sad. Data were gathered by conducting a questionnaire (one for teachers and one for students) and an interview. The teachers' questionnaire had 45 questions, whereas the students' contained 60 questions. Of these, 16 questions were identical and the answers to them were compared using ANOVA. The results reveal that the teachers' and students' views of dictionary use differ significantly with respect to 11 questions. The students primarily use online bilingual dictionaries and tools, whereas the teachers prefer monolingual dictionaries in the form of mobile phone applications. Dictionaries were primarily used for finding word meanings, with students failing to understand all lexicographic information. The results necessitate that both students and teachers receive training in dictionary use and that dictionaries become an obligatory teaching and learning resource.

Key words: dictionaries, ESP learning, ESP teachers, ESP teaching, monolingual dictionaries, bilingual dictionaries, specialized dictionaries, university.

\footnotetext{
*tatjana.glusac@gmail.com

** The paper results from the project entitled "Using Dictionaries in Teaching and Learning English for Specific Purposes in Tertiary Education in Serbia" (No.142-451-3684/2017-01) financed by the Provincial Secretariat for Higher Education and Scientific Research. This paper was presented at the Fifth International Conference on English Studies ELALT 5 held at the Faculty of Philosophy, Novi Sad, Serbia, on March 9, 2019.
} 


\section{INTRODUCTION}

At the turn of the century, researchers noticed a change regarding the use of dictionaries in foreign language teaching: the practice started to gain more attention due to "a profound change of attitude toward vocabulary learning and consequently the renewed interest in dictionary use in the last two decades" (Tono, 2001: 1). Tono (2001: 1-2) reasoned that this shift had occurred as a result of the following three reasons: the lexicon had gained more interest in linguistics, the lexical dimension in foreign language learning had been re-evaluated, and lexicography had made a significant step towards making dictionaries more appealing and approachable to language teachers.

Two decades after the shift, there is still a widely-held belief that dictionary-assisted language learning has numerous advantages (e.g., Yamaizumi, 2014; Milić, Glušac, \& Kardoš, 2018; Milić, Sadri, \& Glušac, 2019a); however, researchers (e.g., El-Sayed \& Siddiek, 2013) believe that the dictionary has yet to be adopted to an appropriate degree as a learning tool or as a teaching resource. Numerous recent studies indicate both that students lack dictionary skills (e.g. Akbari, 2015; Krajka, 2007) and that employing dictionaries as a teaching resource is still not a customary practice in many schools (Milić, Glušac, \& Kardoš, 2018; Milić, Sadri, \& Glušac, 2019a; Knežević, Miškeljin, \& Halupka-Rešetar, 2019). It is believed by many (e.g., Milić, Glušac, \& Kardoš, 2018) that dictionary consultation is important at all levels of education and is further intensified at the college level as many professions possess their own specialized vocabulary whose features need to be learned properly both in a foreign and native language.

The aim of this paper is to explore how congruent are the views of tertiary level Serbian teachers of English for specific purposes (ESP) and their students regarding dictionary use. More specifically, the research aims to answer the following questions:

1. What are ESP students' views on dictionary consultation in language learning?

2. What are ESP teachers' views on the same matter?

3. How congruent are the two groups' views?

4. What implications do the two groups' views have on dictionary use? 


\section{DICTIONARIES IN ESP TEACHING AND LEARNING}

Even though lexicography is a century-old field, the pedagogical aspect of dictionary use has only recently become a topic of interest among theorists and practitioners. Not only is the dictionary a source of semantic, grammatical, and phonological information about the lexicon of a foreign language, but it should serve as a teaching and learning tool in today's Anglo-globalized world.

Dictionary aids in teaching standardization of English-based elements in non-English languages. Since English has become a widely spoken language, it affects the languages it comes in contact with, forcing them to accept foreign words in a more or less adapted form. It is not uncommon, though, that the adaptation is done against the standards of the receiving language; hence, dictionary consultation is beneficial toward the purpose of teaching standardization (Milić, Glušac, \& Kardoš, 2018; Milić, Sadri, \& Glušac, 2019a).

Dictionary use ensures learner autonomy (Leaney, 2007; Yamaizumi, 2014). When they are taught how to read and understand lexicographic information and how to choose or derive the meaning of a lexical item being sought, students become autonomous learners and their chances for successful foreign language mastery and correct vocabulary usage are expanded even after the conclusion of formal education. Since skillful, independent dictionary consultation ensures learner autonomy and increases linguistic competence, many authors (e.g., Asher, 1999; Chambers, 1999) call it a life-skill and equate its importance to that of any kind of literacy (e.g., computer literacy).

Dictionary consultation is part of vocabulary learning strategies. In ESP learning, it is by mastering a specialized register that one can communicate ideas to clients more successfully, "attain academic literacy and be part of chosen academic discourse communities" (Hou, 2014: 28). However, there is still no consensus among researchers and educators regarding the best way to teach specialized vocabulary (Hou, 2014: 29). Nonetheless, researchers and lexicographers agree that specialized dictionary consultation needs to be practiced in ESP learning (Knežević, Miškeljin, \& Halupka-Rešetar, 2019; Milić, Sadri, \& Glušac, 2019b) through activities that require the use of dictionaries (El-Sayed \& Siddiek, 2013). To that end, Nesi (1999) advocates that a six-stage process of dictionary use should be followed. It includes activities before study (assessment on how to design activities that require dictionary consultation and when to apply and evaluate them), activities before dictionary consultation (users decide if dictionary consultation is necessary, what type of dictionary would be appropriate, and what to look up), locating, 
interpreting, and recording entry information, and understanding lexicographic issues (what dictionaries are used for, knowledge of lexicographic terminology, etc.). Moreover, Campoy-Cubillo (2015: 129-138) makes a valuable contribution to the discussion on successful dictionary consultation by proposing dictionary use proficiency levels, specifying thus what a student at a certain level of knowledge can be expected to do with the dictionary as a learning tool.

Successful dictionary consultation requires mastering a set of skills (Campoy-Cubillo, 2015: 132) whose development is continuous and should begin very early. Upon entering university, students are expected to possess relevant dictionary skills, yet they do not receive (enough) instruction in school (Atkins, 1998). Tarp (2012: 95) believes that instruction in dictionary consultation begins with using high-quality dictionaries for the learning of the mother tongue, while Scofield (1982) adds to it the learning of lexicographic conventions. The research carried out by Atkins and Varantola (1998) showed that mere instruction in dictionary use does not ensure students' use of one; they need to be familiarized with its importance. In other words, they need to develop 'dictionary culture', the term that many linguists (e.g., Prćić, 2018; Ramagoshi, 2004) use to denote raising students' awareness of the importance of dictionary consultation and, hence, its regular use.

Pedagogical lexicography has expanded significantly over the last decade or so. In line with this trend, the number of research studies on the application of dictionaries as a teaching resource has increased; nonetheless, many researchers (e.g., Chi, 2003; Tono, 2001) believe additional studies are needed to provide a better insight into how best to utilize dictionaries as a teaching and learning resource. Along the same lines, Miller (2008) points out that teachers are still generally reluctant regarding the utilization of dictionaries for two reasons: (1) they have little awareness regarding dictionary use and (2) the prevailing communicative language teaching approach that favors communication over language accuracy might contribute to poor dictionary activity (Herbst \& Stein, 1987, cited in Miller, 2008: 13).

As for the use of dictionaries employed by learners, many researchers (e.g., Augustyn, 2013; Knežević, Miškeljin, \& Halupka-Rešetar, 2019; Tarp, 2012) claim that students prefer quick search tools (e-dictionaries or other online tools (e.g., Google Translate)) over paper dictionaries. Moreover, students have been found to use dictionary information selectively; they primarily look for word meanings and/or translation equivalents, followed by spelling, and, very rarely, pronunciation (Chi, 1998; Knežević, Miškeljin, \& Halupka-Rešetar, 2019; Milić, Sadri, \& Glušac, 
2019a). Even though students mainly type an unfamiliar word in a search engine and click to get information regarding a particular word, many worry about the lack of their dictionary skills (Miller, 2008), even when they pertain to online searching (Krajka, 2007). Also, as observed by Tono (2001: 36) in his review of different studies on the use of the dictionary in EFL teaching and learning, variables including the students' native language, foreign language proficiency, cognitive skills, and learning styles all contribute to one's successful use of the dictionary. However, the author believes more research is needed to clarify how these variables might impact dictionary use.

\section{METHODOLOGY}

The research this paper is based on was conducted on a sample including 21 ESP teachers and 705 students enrolled in different years of study, all of them from the 11 faculties comprising the University of Novi Sad.

The research included a mixed-model inquiry. The quantitative part presupposed constructing two questionnaires - one for the students and the other for the teachers - whose aim was to explore the use of dictionaries in ESP teaching and learning. The qualitative part was realized by means of a semi-structured interview. Both measuring instruments were conducted in Serbian.

The questionnaire for the teachers included 45 questions that probed their views regarding the types of dictionaries used, reasons for asking students to or not to consult a dictionary, and dictionary skills students need. On the other hand, the questionnaire for the students included 60 questions grouped into the following sections: types of dictionaries used, purposes of dictionary consultation, difficulties in dictionary use, and use of technical dictionaries.

The researchers followed the suggestion put forward by Allen and Seaman (2007) for employment of a four-point Likert scale instead of the five-point version in order to obtain an answer with a specific meaning (always - sometimes rarely - never) rather than the unspecific, omitted option (Not sure or I don't know).

Sixteen questions were identical in the two questionnaires. These related to the types of dictionaries used, the reasons and frequency of their consultation. Only these 16 questions are used for the analysis this paper is based on since the authors' primary aim was to discover the extent of congruence between the teachers' and students' views regarding these questions.

The research was carried out during the spring semester of the 2017/2018 academic year. The students were asked to fill out the printed version of the 
questionnaire, whereas the teachers were instructed to fill out the questionnaire online in the Google Forms format.

The interview was semi-structured, which presupposed that the researchers would follow a set trajectory by asking the same core questions falling in four categories (type of dictionary used, reasons for use, difficulties encountered, and frequency of use). Additional questions were also possible for a more comprehensive insight into a given situation. Twelve students and nine ESP teachers were interviewed.

For the analysis of the questionnaire answers, a one-way ANOVA was used (SPSS 20), as well as the following frequency scale for interpreting the mean results: 1-2 low, 2-3 medium, and 3-4 high frequency. To analyze the interview transcripts, content analysis was applied.

\section{RESULTS}

\section{The results of the questionnaires}

The mean values presented in Table 1 reveal that the frequency of use of all dictionary types falls in the response ranges sometimes and rarely, except for the response for online dictionaries given by the students (it is in the category often). This is indicative of a rather poor employment of dictionaries in ESP teaching and learning at Serbian faculties.

The results in Table 1 also show that of 16 questions (Q/Qs), 11 have statistically different answers (Qs 1, 2, 3, 4, 5, 6, 9, 10, 12, 14, and 16). This indicates that the teachers' and students' views of various aspects of dictionary use differ. For example, there is disagreement with respect to the use of all types of general-purpose dictionaries (Qs 1, 2, and 3). While the mean values show the teachers sometimes ask students to use monolingual dictionaries, the students' answers indicate they rarely use them (Q 1). As for general-purpose bilingual sources (Qs 2 and 3), the answers show that the students tend to use them more than the teachers expect them to do. Moreover, the teachers seem to be requiring their students to use all types of technical dictionaries more than the students actually do (Qs 4, 5, and 6), while the learners seem to be using online dictionaries considerably more than the teachers would want them to (Q 9). Both groups seem to prefer electronic to printed dictionaries (Qs 7 and 8). While the teachers favor a mobile phone application for a dictionary, an e-dictionary and then an online one, respectively, the students' first option is the teachers' least favorite — an online source. 
The results presented in Table 1 also show that of the four questions pertaining to the reason for using a dictionary, the teachers and students disagree with respect to two: the teachers ask their students to consult a dictionary for grammatical information about a word far more than the students actually do (Q 14), and the teachers ask students to check the pronunciation of a word more often than the students truly follow this instruction (Q 12). On the other hand, the two groups share their views regarding the use of dictionaries for the purpose of finding out the meaning of a word ( $Q$ 11) and in searching for a synonym (Q 13), both being the main reasons for dictionary consultation for both groups of respondents.

As for those situations in which the teachers and students deem it necessary to consult a dictionary, the two groups' views differ significantly with respect to employing one in an English class (Q 16) — the teachers ask students to consult a dictionary far more often than the students seem to do so. The teachers indicated sometimes advising students to consult a dictionary when preparing for an English exam, a practice which the students reported as following to a similar degree (Q 15).

Table 1. Comparison of ESP teachers' and students' answers regarding dictionary use

\begin{tabular}{|c|c|c|c|}
\hline Question & Mean & $\mathbf{F}$ & $\mathbf{p}$ \\
\hline \multicolumn{4}{|c|}{ How often do you use / ask your students to use the following dictionaries? } \\
\hline 1. General-purpose English-English dictionary & $\begin{array}{l}\mathrm{T}^{*}: 2.48 \\
\mathrm{~S}^{*}: 1.69\end{array}$ & 17.743 & .000 \\
\hline 2. General-purpose Serbian-English dictionary & $\begin{array}{l}\mathrm{T}: 1.76 \\
\mathrm{~S}: 2.25\end{array}$ & 5.703 & .017 \\
\hline 3. General-purpose English-Serbian dictionary & $\begin{array}{l}\mathrm{T}: 1.86 \\
\mathrm{~S}: 2.27\end{array}$ & 3.907 & .048 \\
\hline 4. Technical English-English dictionary & $\begin{array}{l}\mathrm{T}: 2.19 \\
\mathrm{~S}: 1.51\end{array}$ & 16.418 & .000 \\
\hline 5. Technical Serbian-English dictionary & $\begin{array}{l}\mathrm{T}: 2.43 \\
\mathrm{~S}: 1.63\end{array}$ & 21.265 & .000 \\
\hline 6. Technical English-Serbian dictionary & $\begin{array}{l}\mathrm{T}: 2.24 \\
\mathrm{~S}: 1.65\end{array}$ & 10.895 & .001 \\
\hline 7. Printed dictionary & $\begin{array}{l}\mathrm{T}: 1.71 \\
\mathrm{~S}: 1.85\end{array}$ & .481 & .488 \\
\hline 8. E-dictionary & $\begin{array}{l}\mathrm{T}: 2.71 \\
\mathrm{~S}: 2.51\end{array}$ & .721 & .396 \\
\hline
\end{tabular}


9. Online dictionary

T: 2.43

S: 3.12

12.583

.000

10. Mobile phone application dictionary

T: 2.86

S: 2.13

8.937

.003

Why do you use / ask your students to use a dictionary?

11. To find out the meaning of a new word

$\mathrm{T}: 3.24$

S: 3.17

.131

.717

12. To check pronunciation

T: 2.90

S: 2.14

5.546

.019

13. To find out a synonym

T: 2.48

S: 2.16

2.440

.119

14. To find out grammatical information about a word

$\mathrm{T}: 3.14$

S: 1.77

$50.006 \quad .000$

How often do you use / ask your students to use a dictionary in the following situations?

\begin{tabular}{llll} 
15. When preparing for an exam & T: 2.95 & 1.860 & .173 \\
& S: 2.63 & & \\
\hline 16. During an English class & T: 3.10 & 35.624 & .000
\end{tabular}

${ }^{*}$ T - teachers, S -students

The results of the interview with teachers

The interview results confirm the quantitive data pertaining to the type of dictionary - all the interviewees refer their learners to mobile phone applications in the first place, then other electronic sources, monolingual and technical dictionaries. Five out of nine interviewed teachers do not ask their students to consult dictionaries, yet notice their students use them during class. The remaining four require using them only when learning or practicing new vocabulary.

As opposed to the quantitative data, the interview responses show the major reasons for dictionary consultation include the improvement of the overall knowledge of English, learner autonomy, and access to better quality information. All the interviewees are found to be the main source of vocabulary information for their students during classwork.

The interviewees reported difficulties in employing all dictionary types and they seem to be of technical (lack of printed copies in faculty libraries, lack of students' dictionary skills), organizational (busy syllabi, a small number of classes), 
and financial (cost of printed dictionaries) nature. Most respondents did show awareness of printed sources being most reliable.

As for the frequency of use, the teachers' answers range from the statement that the dictionary has never been used more (1 teacher), over the opinion that dictionaries should be used considerably more (6 teachers) to the claim that they should not be used at all (2 teachers).

\section{The results of the interview with students}

Most students refer to an online source, predominantly Google Translate as they consider it a dictionary. Four students, however, typically type a word in a search engine and look at the first few links trying to guess the meaning of the word they are looking for. One student always uses a monolingual dictionary and one a printed source. Only three students know of technical dictionaries in their fields of study, yet they rarely use them.

The goal of all the students' searching is exclusively word meaning, preferably given in the form of a translation equivalent. However, when in class, they report no need to consult a dictionary as the teacher is the source of all needed information or the new foreign word is similar in shape to its Serbian equivalent.

When asked about their preference for online sources, students mentioned they are available at all times, the search is easy and quick and audio pronunciation is offered. Three students, though, refer to printed dictionaries when they need accurate information.

The interviewees' answers reveal they typically face challenges of technical, practical, and personal nature only when consulting a printed source. Technical issues include bulkiness, while practical relate to printed sources not being available at all times, their search being lengthier, not understanding all lexicographic information and their outdatedness. Among personal reasons, respondents reported believing Google Translate is unreliable and their lack of dictionary skills. They all think foreign language students should be trained in dictionary use.

\section{DISCUSSION}

The obtained results clearly show that there is more dissonance than congruence between the teachers' and students' responses.

The ESP teachers favor and refer their students to mobile applications, monolingual and technical dictionaries. However, when the mean values of the use 
of these types of dictionary are taken into account, it is obvious the teachers only rarely recommend their use. The same finding has also been observed by Milić, Sadri and Glušac (2019b), who have appealed for a greater use of good quality specialized dictionaries in ESP learning. The teachers were shown to prefer, and refer their students mostly to, mobile application dictionaries, as they are an electronic version of reliable printed dictionaries containing all important information. The respondents did express their awareness of printed dictionaries as reliable and trustworthy, but they are employed least of all the other types.

The students most readily consult online sources (Google Translate), searching mainly for word meanings or translation equivalents. They seem to favor electronic dictionary resources due to their portability, their ease and speed of use, the ready-made answers they offer and the advantage that they do not require the considering of information that is not of primary interest to them at the moment of search. The same finding was obtained by Cook (2010, cited in Augustyn, 2013: 367), whose respondents were found to readily use smart phones or tablets that allow for easy access to Google Translate in search for a translation equivalent. These results also corroborate those of Miller (2008) - students mostly rely on bilingual electronic dictionaries. Béjoint and Moulin (1987) explain bilingual dictionary preference by stating that it is suitable for cursory consultations. Lexicographers have also come to realize that quick and easy access to dictionary data has become a necessity and are striving to design such reference books (Tarp, 2012).

As evidenced by other research studies (e.g., Miller, 2008), the results obtained through this research revealed that students mainly use bilingual dictionaries, while teachers prefer monolingual ones. Students seem to be seeking ready-made solutions, while teachers likely base their preference for monolingual dictionaries on the belief that they do not offer instant solutions, but rather require students to derive a solution by studying the given information by a monolingual source. Such a practice necessitates students' immersion in implicit language learning, which results in improved linguistic proficiency. Augustyn (2013) explains that even though no clear advantage of monolingual or bilingual teaching has been strongly supported by research findings, translation is undeservedly ignored in foreign language teaching to the expense of monolingual teaching. Discovering translation equivalents and contrastive analysis are desirable language learning strategies since the use of the mother tongue in the classroom has many important pedagogical, cognitive, and social functions (Augustyn, 2013: 366). Therefore, using a bilingual dictionary that offers ready-made solutions and 
standardized forms of technical terms has not been found to have a negative impact on student' learning (Milić, Glušac, \& Kardoš, 2018).

Another advantage of consulting bilingual dictionaries in ESP learning is the teaching of standardization (Milić, Sadri, \& Glušac, 2019a). In the case of Serbian, the process of lexical borrowing in the specialized register from English is realized by means of adapting foreign terms in Serbian (Milić, 2015), frequently without respecting the rules of the receiving language. For that reason, consulting a bilingual technical dictionary would enable learning of such word forms that are in alignment with the standards of the receiving language, thus contributing to the preservation of the learners' mother tongue and their more accurate linguistic expression. However, the results of this research show that teachers rarely ask students to consult technical or bilingual dictionaries.

As for the purpose of using dictionaries, all respondents principally see the dictionary as a source of information on the meaning of words and/or translation equivalents. However, their views display a dissonance when it comes to viewing a dictionary as a source of grammatical information about words. The teachers seem to ask their students to look for grammatical or phonological information much more often than students actually do. Similar results were reported in the studies conducted by Miller (2008) and Milić, Sadri and Glušac (2019a).

Both groups' answers are congruent in that students should consult a dictionary when preparing for an exam, which they indeed seem to be doing. On the other hand, the results reveal that a dictionary is rarely used in class since either the teacher provides all needed information or the shape of the English word is so similar to the corresponding term in Serbian that they can guess its meaning.

As far as dictionary skills are concerned, the students' interview responses reveal that they are aware of their own lack of knowledge of lexicographic conventions and they believe foreign language students should be trained in dictionary use. The students are also aware of the limitations and inadequateness of online search tools, but their lack of dictionary skills and the practiced teaching routine seem not to require them to use a more reliable source.

\section{CONCLUSION}

Dictionary use in ESP teaching and learning at the University of Novi Sad is rather infrequent and sporadic and there has been found a great dissonance in ESP teachers' and their students' views regarding dictionary use.

Both teachers and students face challenges in consulting printed dictionaries. For that reason, teachers require students to use mobile phone 
dictionary applications, typically monolingual, but the students seem to choose bilingual dictionaries or Google Translate instead as they offer instant, ready-made solutions. Both groups' preference for online/electronic sources points to the need for producing good quality electronic dictionaries. However, the results necessitate that students should be instructed on the benefits and trustworthiness of different sources of linguistic information. Also, the fact that both groups see the dictionary primarily as a source of word meanings and/or translation equivalents calls for teachers being informed and trained in how to employ dictionaries for other purposes as well, while students need to be instructed on how to use all dictionary information.

The findings also imply that the time may have come to reconsider the employment of bilingual dictionaries in ESP learning in order to discuss the sameness and differentness between the words in the two languages, as well as to teach standardization rules of the mother tongue, for which reason a sizable portion of an ESP class might need to be realized in the mother tongue.

Further studies investigating dictionary use are both possible and paramount. As suggested by Tono (2001: 36), it would be beneficial to investigate the impact of different variables (native language background, foreign language proficiency, cognitive skills, and learning styles) on dictionary use. Also, it would be worthwhile to conduct research after a systematic training of students in dictionary consultation so as to evaluate their competence in applying this resource. Moreover, as the training of ESP teachers in employing dictionaries is also desirable, a study could be conducted to assess their success in making use of this fundamental reference tool.

Tatjana Glušac, Mira Milić

KAKO UNIVERZITETSKI NASTAVNICI ENGLESKOG JEZIKA STRUKE I NJIHOVI STUDENTI KORISTE REČNIKE U PODUČAVANJU I UČENJU

\section{Rezime}

U radu se upoređuju stavovi nastavikâ engleskog jezika struke koji predaju na univerzitetskom nivou i njihovih studenata u vezi sa upotrebom rečnikâ u procesu podučavanja i učenja jezika. U istraživanju su učestvovali 21 nastavnik i 705 studenata novosadskog univerziteta. Podaci su prikupljeni tehnikom upitnika (posebne verzije za nastavnike i studente) i polustruktuiranog intervjua. Od ukupno 45 pitanja za nastavnike i 60 za studente u sklopu upitnika, 16 ih je bilo identično, te odgovori na njih predstavljaju osnov za izradu ovog rada. Odgovori na pomenuta pitanja obrađeni su postupkom ANOVA, a 
rezultati intervjua metodom analize sadržaja. Srednje vrednosti odgovora otkrivaju da se sve vrste rečnika nedovoljno koriste u procesu podučavanja i učenja. Takođe, kod 11 od 16 analiziranih pitanja utvrđena je statistički značajna razlika u odgovorima između dve grupe ispitanika, što ukazuje na to da se njihovi stavovi o raznim aspektima upotrebe rečnikâ znatno razlikuju. Studenti uglavnom koriste onlajn dvojezične izvore radi bržeg pronalaženja gotovih odgovora, dok ih nastavnici upućuju na jednojezične rečničke aplikacije za mobilne telefone misleći da će ih tako više uključiti u proces implicitnog učenja jezika. Obe grupe slabo koriste štampani rečnik zbog njegovih brojnih nedostataka i poteškoća koje nastaju njegovom primenom, ali su svesne pouzdanosti ovog izvora informacija. Uočena je i prilično retka upotreba stručnih rečnika, ponajviše zbog načina rada nastavnika (on se postavlja kao primarni izvor svih potrebnih informacija) i usled činjenice da su strani termini često slični po obliku svojim ekvivalentima u srpskom jeziku, te studenti lako zaključe njihovo značenje. Obe grupe prevashodno koriste rečnik kao izvor informacija u vezi sa značenjem reči, zanemarajući ostale informacije iz rečničkog članka. Dobijeni rezultati ukazuju na potrebu da se i studenti i nastavnici obuče u vezi sa upotrebom rečnikâ i da oni treba da postanu obavezno nastavno sredstvo.

Ključne reči: rečnici, engleski jezik struke, nastavnici engleskog jezika struke, univerzitet, dvojezični rečnik, jednojezični rečnik, stručni rečnik.

\section{REFERENCES}

Akbari, Z. (2015). Key vocabulary learning strategies in ESP and EGP course books. International Journal of Applied Linguistics and English Literature, 4(1), 1-7. DOI: 10.7575/aiac.ijalel.v.4n.1p.1

Allen, E. \& Seaman, C. (2007). Likert scales and data analyses. Quality Progress, 40(7), 64-65.

Asher, C. (1999). Using dictionaries in the GCSE examination of modern foreign languages: Teachers' views and learners' performance. Studies in Modern Language Education, 7(1), 59-67.

Atkins, S. (1998). Introduction. In: Atkins, S. (Ed.) (1998). Using Dictionaries: Studies of Dictionary Use by Language Learners and Translators. Tübingen: Max Niemeyer Verlag. 1-5.

Atkins, S. \& Varantola, K. (1998). Monitoring dictionary use. In: Atkins, S. (Ed.) (1998). Using Dictionaries: Studies of Dictionary Use by Language Learners and Translators. Tubingen: Max Niemeyer Verlag. 84-122.

Augustyn, P. (2013). No dictionary in the classroom: Translation equivalents and vocabulary acquisition. International Journal of Lexicography, 26(3), 362285. DOI: 10.1093/ijl/ect017 
Béjoint, H. \& Moulin, A. (1987). The place of dictionary in an EFL programme. In: Anthony, C. (Ed.) (1998). The Dictionary and the Language Learner: Papers from the EURALEX Seminar at the University of Leeds. Tübingen: Niemeyer. 97-114.

Campoy-Cubillo, M. C. (2015). Assessing dictionary skills. Lexicography, 2(1), 119-141. DOI: 10.1007/s40607-015-0019-2.

Chambers, G. (1999). Using dictionaries in the GCSE examination of modern foreign languages: Pupils' perceptions. Studies in Modern Language Education, 7(1), 68- 85.

Chi, M. L. A. (1998). Teaching dictionary skills in the classroom. In: Fontenelle, T.-Hiligsmann, P.-Michiels, A.-Moulin, A. \& Theissen, S. (Eds.) (1998). Euralex'98 Proceedings. Papers Submitted to the Eighth EURALEX International Congress on Lexicography in Liège, Belgium. Liège: Université de Liège, Départements d'anglais et de néerlandais. 565-577.

Chi, M. L. A. (2003). An Empirical Study of the Efficacy of Integrating the Teaching of Dictionary Use into a Tertiary English Curriculum in Hong Kong. Hong Kong: Language Centre, Hong Kong University of Science and Technology.

El-Sayed, A. A. A. \& Siddiek, A. G. (2013). Review of EFL learners' habits in the use of pedagogical dictionaries. English Language Teaching, 6(8), 54-65. DOI: $10.5539 /$ elt.v6n8p54

Hou, H-I. (2014). Teaching specialized vocabulary by integrating a corpus-based approach: Implications for ESP course design at the university level. English Language Teaching, 7(5), 26-37. DOI:10.5539/elt.v7n5p26

Knežević, Lj., Miškeljin, I. \& Halupka-Rešetar, S. (2019). Upotreba rečnika u nastavi engleskog jezika struke iz ugla nastavnika [The use of dictionaries in teaching English for specific purposes from the teachers' perspective]. In: Gudurić, S. \& Radić Bojanić, B. (Eds.) (2019). Jezici i kulture u vremenu i prostoru 8 [Languages and Cultures in Time and Space 8]. Novi Sad: Filozofski fakultet. 489-494.

Krajka, J. (2007). Online lexicological tools in ESP - towards an approach to strategy training. Scripta Manent, 3(1), 3-19.

Leaney, C. (2007). Dictionary Activities. Cambridge: Cambridge University Press.

Miller, J. (2008). Teachers and dictionary in Australia: Is there a need to train the trainers? TESOL in Context, 17(2), 11-19.

Milić, M. (2015). Creating English-based sports terms in Serbian: Theoretical and practical aspects. Terminology, 21(1), 1-22. DOI: 10.1075/term.21.1.01mil 
Milić, M., Glušac, T. \& Kardoš, A. (2018). The effectiveness of dictionary-aided teaching standardization of English-based sports terms in Serbian. Lexikos, 28, 262-286. DOI: 10.5788/28-1-1465

Milić, M., Sadri, F. \& Glušac, T. (2019a). The pedagogical potential of a bilingual specialized dictionary in tertiary education. EQOL Journal 11(1), 51-58. DOI: $10.31382 /$ eqol.190606

Milić, M., Sadri, F. \& Glušac, T. (2019b). The pedagogical potential of a userfriendly specialized dictionary in function of adopting a healthy lifestyle. BMC Sports Science, Medicine and Rehabilitation, 11(7), 5.

Nesi, H. (1999). The specification of dictionary reference skills in higher education. In: Hartmann, R. (Ed.) (1999). Dictionaries in Language Learning. Recommendations, National Reports and Thematic Reports from the TNP Sub-Project 9: Dictionaries. Berlin: Free University Berlin. 53-66.

Prćić, T. (2018). Ka savremenim srpskim rečnicima, Prvo, elektronsko, izdanje [Towards Modern Serbian Dictionaries. First Digital Edition]. Novi Sad: Filozofski fakultet.

Ramagoshi, R. (2004). The use of dictionaries in the light of language teaching methods. Lexikos, 14, 253-263.

Scofield, P. (1982). Using the English dictionary for comprehension. TESOL Quarterly, 16(2), 185-194.

Tarp, S. (2012). New experiences in pedagogical lexicography: Two Cuban school dictionaries. Hermes - Journal of Language and Communication in Business, 48, 95-107. DOI: 10.7146/hjlcb.v25i48.97428

Tono, Y. (2001). Research on Dictionary Use in the Context of Foreign Language Learning. Focus on Reading Comprehension. Tübingen: Max Niemeyer Verlag.

Yamaizumi, M. (2014). Teaching English-Japanese dictionary use in university remedial courses. Komaba Journal of English Education, 5, 1-28. Available at http://park.itc.u-tokyo.ac.jp/eigo/KJEE/005/001-028.pdf. Accessed: 13 November 2019. 